\title{
Analisis Kinerja Kemandirian Keuangan UKM dan Aktivitas Produksi Produk Olahan Ikan pada UD. Permata Indah Situbondo Dengan Metode Actyvity Based Costing (Abc)
}

\author{
Ratnaning Tyasasih ${ }^{1}$ dan Triska Dewi Pramitasari ${ }^{2}$ \\ Fakultas Ekonomi Universitas Abdurachman Saleh Situbondo
}

Email: ratnaning018@gmail.com, triskadp1005@gmail.com

Kata kunci:

UKM, HPP, Metode ABC, Aktivitas

Produksi, Kinerja Kemandirian Keuangan.

\section{Keywords:}

UKM, HPP, ABC Method, Production

Activities, Financial

IndependencePerformance.

Ratnaning Tyasasi, Triska Dewi

Pramitasari: Analisis Kinerja

Kemandirian Keuangan Ukm Dan

Aktivitas Produksi Produk Olahan Ikan

Pada Ud. Permata Indah Situbondo

Dengan Metode Actyvity Based Costing

(Abc), $12(2), 1-11$

Https://Doi.Org/10.35457/Akuntabilitas. $\underline{V 12 i 1.720}$

\begin{abstract}
ABSTRAK
Tujuan penelitian ini adalah untuk menganalisa kinerja kemandirian keuangan dan aktivitas produksi UKM. Metode analisa data meliputi perhitungan HPP menggunakan metode Activity Based Costing (ABC), analisis aktivitas produksi dan analisis kemandirian keuangan UKM. Hasil penelitian menunjukkan perhitungan HPP lebih akurat menggunakan metode $\mathrm{ABC}$, dimana 3 produk (dendeng, petis dan abon ikan) mengalami undercosting, sedangkan 3 produk lainnya (kripik, krupuk dan teri krispi) mengalami overcosting. Hasil analisis aktivitas produksi UKM lebih besar dibandingkan standar rasio industri aktivitas dimana nilai total aset turn over sebesar $3 x(>2 x)$ dan perputaran piutang sebesar 16x (>15x). Hasil analisis tingkat kemandirian keuangan UKM memiliki nilai rentabilitas aset dan rentabilitas modal sendiri lebih besar dari 10 (standar pengukuran) serta nilai kemandirian operasional UKM lebih besar dari 100 (standar pengukuran). Sehingga dapat disimpulkan bahwa UD. Permata Indah merupakan UKM yang sehat, efektif dan mandiri secara keuangan.
\end{abstract}

\section{ABSTRACT}

The purpose of this study is to analyze the performance of financial independence and SME production activities. Data analysis methods include the calculation of COGS using Activity Based Costing $(A B C)$, production activity analysis and SME financial independence analysis. The results showed that the calculation of COGS was more accurate using the $A B C$ method, where 3 products (jerky, petis and shredded fish) were undercosting, while 3 other products (chips, crackers and anchovies) were overcosting. The results of the SME production activity analysis are greater than the industry activity standard ratio where the total value of assets turnover is $3 x(>2 x)$ and accounts receivable turnover is $16 x(>15 x)$. The results of the analysis of the level of financial independence of SMEs have the value of the profitability of assets and the profitability of their own capital greater than 10 (measurement standards) and the value of the operational independence of SMEs greater than 100 (measurement standards). So it can be concluded that UD. Permata Indah is a healthy, effective and financially independent SME.

\section{PENDAHULUAN}

Menghadapi persaingan pasar, setiap produsen khususnya UKM (usaha kecil menengah) tidak hanya dituntut untuk menciptakan produk yang berkualitas 
baik dan inovatif namun juga persaingan harga yang terjangkau dikalangan masyarakat. Untuk itu Sedarmayanti (2012) menyatakan perlu perencanaan yang tepat dalam pengalokasian biaya untuk menciptakan perbandingan yang baik antara hasil yang diperoleh dengan kegiatan yang dilakukan atau biasa disebut dengan istilah efisiensi dalam menentukan harga pokok produksi.

Pengalokasian penentuan harga pokok produksi UKM (Usaha Kecil Menengah) atas produk yang dihasilkan sangat penting, karena selain berkaitan dengan harga jual atas produk yang nantinya berpengaruh pada kelangsungan hidup usaha, juga dapat mempengaruhi kemandirian keuangan UKM itu sendiri. Penetapan harga pokok produksi di UD. Permata Indah selama ini hanya didasarkan pada perkiraan, kepantasan, dan perbandingan dengan harga pokok produksi dari perusahaan pesaing, karena biaya produksi belum pernah dihitung secara benar.

Perhitungan yang tidak akurat akan memberikan informasi biaya yang terdistorsi, baik undercosting maupun overcosting yang mengakibatkan kesalahan pengambilan keputusan, penentuan biaya, pembuatan keputusan, perencanaan dan pengendalian, serta kelangsungan usaha. Kelemahan sistem penetapan HPP tersebut dapat diperbaiki melalui penerapan sistem penentuan HPP berdasarkan aktivitas atau lebih dikenal dengan metode Activity Based Costing (ABC). Merode ABC dapat meningkatkan ketelitian dalam perincian biaya dan ketepatan pembebanan biaya lebih akurat (Mulyadi, 2015).

Sebagai UKM, UD Permata Indah dituntut untuk lebih meningkatkan kinerja dan mutu produknya, tetapi harus tetap dalam koridor efisiensi anggaran. Tuntutan ini dapat dipenuhi melalui pemotongan alur birokrasi yang bersifat non value added activities pada sistem manajemen UKM, sehingga dapat mencegah terjadinya keterlambatan penjualan produk serta pemborosan sumber daya. Pengelolaan aktivitas memerlukan pemahaman terhadap penyebab biaya aktivitas. Analisis aktivitas menghasilkan: (1) aktivitas apa yang dilakukan, (2) bagaimana aktivitas dilakukan, (3) waktu dan sumber daya yang diperlukan untuk melakukan aktivitas, dan (4) penilaian terhadap aktivitas (bernilai tambah \& tidak bernilai tambah). Identifikasi aktivitas yang tidak bernilai tambah diperlukan dalam pengelolaan aktivitas guna pengurangan biaya (cost reduction). 
Pengurangan biaya akan mengurangi harga pokok produksi, sehingga biaya produksi lebih efisien dan tingkat kemandirian keuangan perusahaan dapat ditingkatkan.

Penelitian mengenai penetapan harga pokok produk menggunakan metode Activity Based Costing $(A B C)$ telah dilakukan oleh beberapa peneliti. Penelitianpenelitian tersebut mengemukakan adanya research gap tentang penetapan harga pokok produk menggunakan metode Activity Based Costing ( $A B C$ ). Hasil studi Kapojos, Sondakh dan Waladouw (2014) menunjukkan bahwa metode ABC menghasilkan perhitungan HPP yang sama untuk seluruh produk perusahaan Roti Lidya, yaitu memberikan hasil yang lebih tinggi dari cara tradisional. Sedangkan menurut Saputri (2013) menunjukkan bahwa metode ABC menghasilkan perhitungan HPP yang berbeda untuk masing-masing produk, yaitu HPP pada tas selempang lebih murah $\mathrm{Rp} 14.674,79 /$ unit dari sistem konvensional, pada ransel selisih $\mathrm{Rp}$ 28.960,85/unit lebih besar dari sistem konvensional (undercost) dan pada tas laptop lebih murah Rp 3.817,78/unit dari sistem konvensional. Hasil penelitian ini konsisten dengan hasil penelitian dari Tyasasih dan Pramitasari (2019), A'isyah dan Azizah (2013), Puspitawati (2013), Rajabi dan Dabiri (2012), dan Putri dan Sabeni (2011). Berdasarkan uraian diatas maka tujuan dari penelitian ini adalah untuk menganalisa kinerja kemandirian keuangan dan aktivitas produksi UKM.

\section{METODE PENELITIAN}

\section{Metode Pengumpulan Data}

1. Dokumentasi

Dokumentasi menurut Sugiyono (2017) merupakan catatan peristiwa yang sudah berlalu. Dalam penelitian ini metode dokumentasi digunakan untuk mengumpulkan data tentang biaya-biaya yang ada kaitannya dengan penentuan harga pokok produksi pada UD Permata Indah yang meliputi data BBB, BTK, BOP pada tahun 2018, serta data mengenai jumlah karyawan, jumlah jam kerja, jumlah KWH (untuk pemakaian tenaga listrik), dan luas area usaha yang digunakan untuk proses produksi. 


\section{Wawancara}

Wawancara menurut Arikunto (2016) adalah sebuah dialog yang dilakukan pewawancara untuk memperoleh informasi dari terwawancara. Wawancara yang diguanakan dalam penelitian ini adalah jenis wawancara terstruktur, dengan membuat pertanyaan-pertanyaan terlebih dahulu sebelum wawancara. Data yang diperoleh dalam penelitian ini adalah identifikasi aktivitas apa saja yang berpengaruh terhadap penentuan HPP serta profil UD. Permata Indah.

\section{Metode dan Analisis Data}

\section{Perhitungan HPP dengan Metode ABC}

Metode $\mathrm{ABC}$ dihitung menggunakan pendekatan yang terdiri dari dua tahap yaitu :

a) Prosedur Tahap Pertama

Pada tahap pertama ada 5 langkah yang perlu dilakukan menurut Mulyadi (2015) yaitu :

1) Mengidentifikasi aktifitas.

Aktivitas yang dilakukan dalam pembuatan produk olahan ikan adalah: pengumpulan ikan, filet atau penghalusan ikan, pencampuran bumbu, pengukusan adonan, perajangan, penjemuran, penggorengan, spiner produk jadi, pengemasan.

2) Membebankan biaya ke aktivitas

Biaya yang dikeluarkan dalam proses produksi produk olahan ikan antara lain: biaya bahan penolong, biaya air minum, biaya listrik, biaya pengemasan, biaya pengiriman, dan biaya telepon.

3) Mengelompokkan aktivitas sejenis untuk membentuk kumpulan sejenis.

Mengelompokkan aktivitas yang saling berkaitan untuk membentuk kumpulan yang sejenis (homogen).

4) Menjumlahkan biaya aktivitas yang dikelompokkan untuk mendefinisikan kelompok biaya sejenis. Mengelompokkan biaya aktivitas yang telah dikelompokkan untuk mendefinisikan kelompok biaya sejenis (homogeneous cost pool). 
5) Menghitung kelompok tarif overhead

Tarif pool $=\underline{\text { BOP kelompok aktivitas tertentu }}$ driver biayanya

b) Prosedur Tahap Kedua

Pada tahap kedua, biaya dari setiap kelompok overhead ditelusuri ke produk, dengan menggunakan tarif kelompok yang telah dihitung. Pembebanan overhead dari setiap kelompok biaya pada setiap produk dihitung dengan rumus sebagai berikut:

Overhead yang dibebankan $=$ tarif kelompok $\chi$ unit driver yang dikonsumsi Selanjutnya, harga pokok produksi dapat dihitung dengan menjumlahkan seluruh biaya yang digunakan, terdiri dari biaya bahan baku, biaya tenaga kerja, dan biaya overhead pabrik dibagi per unit produk yang dihasilkan oleh perusahaan.

\section{Analisis Aktivitas}

Analisis aktifitas harus menunjukkan empat hasil yaitu (1) aktifitas apa saja yang dilakukan, (2) berapa banyak orang yang melakukan aktifitas tersebut, (3) waktu dan sumber daya yang dibutuhkan untuk melakukan berbagai aktifitas, dan (4) penilaian atas nilai aktifitas bagi UKM, termasuk sarana untuk memilih dan mempertahankan berbagai aktivitas yang menambah nilai. Rasio Aktivitas yang digunakan terdiri dari :

a) Total Aset Turn Over menunjukkan perputaran total aktiva diukur dari volume penjualan dengan kata lain seberapa jauh kemampuan semua aktiva menciptakan penjualan (Amminatuzzarah dan Mawardi, 2010). Dengan rumus $=($ penjualan $/$ total aktiva $) \times 100 \%$

b) Perputaran Piutang menunjukkan berapa kali suatu perusahaan menagih piutangnya dalam suatu periode (Soemarso, 2010). Dengan rumus = penjualan bersih / rata-rata piutang

c) Standar pengukuran :

Tabel 1.

Standar Pengukuran Rasio

\begin{tabular}{crc}
\hline No & Jenis Rasio & Standar Industri \\
\hline 1 & Total Aset Turn Over & $2 \mathrm{x}$
\end{tabular}




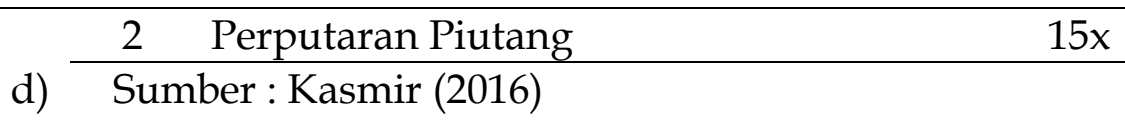

\section{Tingkat Kemandirian Keuangan}

Kinerja keuangan suatu UKM dapat menggambarkan tingkat kesehatan keuangan serta ketergantungan UKM terhadap dana pinjaman yang diberikan oleh pihak kreditur. Indikator yang digunakan untuk mengukur kinerja keuangan yaitu Tingkat Kemandirian Keuangan UKM. Semakin besar Tingkat Kemandirian Keuangan UKM, maka kinerja keuangan UKM semakin bagus. Rasio kemandirian dan pertumbuhan yang digunakan terdiri dari:

a) Rentabilitas Aset (RA) adalah: mengukur kemampuan dari modal yang diinvestasikan dalam keseluruhan aktivitas untuk menghasilkan keuntungan bagi semua penanam modal. Dengan rumus $=$ (laba usaha/total asset) $x$ $100 \%$

b) Rentabilitas Modal Sendiri (RMS) adalah: mengukur kemampuan modal sendiri untuk menghasilkan keuntungan UKM. Dengan rumus = (laba usaha/total modal sendiri) x $100 \%$

c) Kemandirian operasional adalah mengukur kemampuan UKM dalam menghasilkan keuntungan dengan rumus

$=($ laba kotor $/$ beban usaha) $\times 100 \%$.

d) Standar pengukuran:

Tabel 2. Standar Pengukuran Rasio Kemandirian dan Pertumbuhan

\begin{tabular}{cc}
\hline Jenis Rasio & Predikat \\
\hline a.Rentabilitas Aset & Tidak sehat \\
$\leq 5$ & Kurang sehat \\
$5<x \leq 7,5$ & Cukup sehat \\
$7,5<x \leq 10$ & Sehat \\
$>10$ & \\
$\leq 5$ & Tidak sehat \\
$5<x \leq 7,5$ & Kurang sehat \\
$7,5<x \leq 10$ & Cukup sehat \\
$>10$ & Sehat \\
\hline b.Rentabilitas Modal Sendiri & \\
$\leq 100$ & Tidak sehat \\
$>100$ & Sehat \\
\hline
\end{tabular}

Sumber : Kasmir (2016) 


\section{HASIL DAN PEMBAHASAN}

\section{Profil Objek Penelitian}

UD. Permata Indah adalah UKM yang bergerak dalam bidang industry pengolahan ikan. UKM ini didirikan pada tanggal 1 Januari 2015 oleh ibu Yusamma. Usaha ini memperoleh ijin usaha atau SIUP dengan nomer: 503/06/431.405.2/2016 tertanggal 7 Januari 2016. Adapun lokasi dari UD. PERMATA INDAH terletak di Desa Kilensari Kecamatan Panarukan Kabupaten Situbondo. Jenis pruduk yang dihasilkan diantaranya adalah kripik (kapasan, jambrong dan lele), krupuk (ikan, cumi dan lele), abon ikan tuna, dendeng, petis ikan tuna, teri krispi, rengginang, ikan asin, nugget, bakso ikan, pizza ikan, dan rolade ikan.

\section{Harga Pokok Produksi (HPP)}

Perhitungan HPP dalam penelitian ini menggunakan dua metode yaitu metode tradisional dan $\mathrm{ABC}$. Adapun perbandingan hasil perhitungan HPP adalah sebagai berikut :

Tabel 3. Harga Berdasarkan Sistem Tradisional

\begin{tabular}{|c|c|c|c|c|c|}
\hline No. & Produk & BBB & Biaya TKL & BOP & HPP \\
\hline 1 & Kripik & Rp 208.800.000 & $\operatorname{Rp} 8.000 .000$ & $\mathrm{Rp} 87.758 .600$ & $\operatorname{Rp} 304.558 .600$ \\
\hline 2 & Krupuk & Rp 20.880 .000 & $\operatorname{Rp} 8.000 .000$ & Rp 64.173 .600 & Rp 93.053.600 \\
\hline 3 & Dendeng & $\mathrm{Rp} \quad 5.760 .000$ & $\operatorname{Rp} 8.000 .000$ & $\operatorname{Rp} 11.426 .400$ & $\operatorname{Rp} \quad 25.186 .400$ \\
\hline 4 & Petis & - & $\operatorname{Rp} 8.000 .000$ & $\operatorname{Rp} 15.249 .300$ & Rp 23.249 .300 \\
\hline 5 & Abon & $\operatorname{Rp} 33.600 .000$ & $\operatorname{Rp} 8.000 .000$ & Rp 38.299.400 & Rp 79.899 .400 \\
\hline 6 & Teri Crispi & Rp 24.960 .000 & Rp 8.000.000 & Rp 58.459.300 & Rp 91.419.300 \\
\hline \multicolumn{2}{|r|}{ Jumlah } & Rp 294.000.000 & Rp48.000.000 & Rp 275.366.600 & $\operatorname{Rp} 617.366 .600$ \\
\hline
\end{tabular}

Sumber : hasil yang diolah, 2019

Tabel 3 menunjukkan hasil perhitungan HPP dengan metode tradisional, dimana diperoleh nilai HPP untuk produk kripik sebesar Rp 304.558.600,- ; produk krupuk sebesar Rp 93.053.600,- ; produk dendeng sebesar Rp 25.186.400,- ; produk petis sebesar Rp 23.249.300,- ; produk abon sebesar Rp 79.899.400,- ; dan produk teri krispi sebesar Rp 91.419.300,-

Tabel 4. Harga Berdasarkan Metode Activity Based Costing

\begin{tabular}{|c|c|c|c|c|c|}
\hline No. & Produk & BBB & Biaya TKL & BOP & HPP \\
\hline 1 & Kripik & Rp 208.800.000 & $\operatorname{Rp} \quad 8.000 .000$ & $\operatorname{Rp} \quad 67.646 .649$ & $\operatorname{Rp} 284.446 .649$ \\
\hline 2 & Krupuk & $\operatorname{Rp} \quad 20.880 .000$ & 8.000 .000 & 42.049 .493 & Rp 70.929 .493 \\
\hline
\end{tabular}




\begin{tabular}{|c|c|c|c|c|c|c|c|c|}
\hline 3 & Dendeng & $\mathrm{Rp}$ & 5.760 .000 & $\mathrm{Rp}$ & 8.000 .000 & $\mathrm{Rp}$ & 36.523 .584 & $\operatorname{Rp} \quad 50.283 .584$ \\
\hline 4 & Petis & & - & $\mathrm{Rp}$ & 8.000 .000 & $\mathrm{Rp}$ & 36.794 .595 & $\operatorname{Rp} \quad 44.794 .595$ \\
\hline 5 & Abon & $\mathrm{Rp}$ & 33.600 .000 & $\mathrm{Rp}$ & 8.000 .000 & $\mathrm{Rp}$ & 64.838 .919 & $\operatorname{Rp} 106.438 .919$ \\
\hline & Teri Crispi & $\mathrm{Rp}$ & 24.960 .000 & $\mathrm{Rp}$ & 8.000 .000 & $\mathrm{Rp}$ & 26.074 .920 & Rp 59.034 .920 \\
\hline & umlah & $\mathrm{Rp}$ & 94.000 .000 & $\mathrm{Rp}$ & 48.000 .000 & $\mathrm{Rp}$ & 273.928 .160 & $\operatorname{Rp} 615.928 .160$ \\
\hline
\end{tabular}

Sumber : hasil yang diolah, 2019

Tabel 4 menunjukkan hasil perhitungan HPP dengan metode ABC, dimana niai HPP untuk produk kripik sebesar Rp 284.446.649,- ; produk krupuk sebesar Rp 70.929.493,- ; produk dendeng sebesar Rp 50.283.584,- ; produk petis sebesar Rp 44.794.595,- ; produk abon sebesar Rp 106.438.919,- ; dan produk teri krispi sebesar Rp 59.034.920,-

Tabel 5. Perbedaan Nilai HPP antara Metode Tradisional dan ABC

\begin{tabular}{|c|c|c|c|c|c|}
\hline \multirow{2}{*}{ No. } & \multirow{2}{*}{$\begin{array}{c}\text { Jenis } \\
\text { Produk }\end{array}$} & \multicolumn{2}{|c|}{ HPP } & \multirow{2}{*}{ Selisih } & \multirow{2}{*}{ Keterangan } \\
\hline & & Tradisional & $\mathrm{ABC}$ & & \\
\hline 1 & Kripik & $\operatorname{Rp} 304.558 .600$ & $\operatorname{Rp} 284.446 .649$ & $\operatorname{Rp} 20.111 .951$ & Overcosted \\
\hline 2 & Krupuk & Rp 93.053 .600 & $\begin{array}{ll}\text { Rp } & 70.929 .493\end{array}$ & $\operatorname{Rp} 22.124 .107$ & Overcosted \\
\hline 3 & Dendeng & $\operatorname{Rp} \quad 25.186 .400$ & $\operatorname{Rp} \quad 50.283 .584$ & $\operatorname{Rp} 25.097 .184$ & Undercosted \\
\hline 4 & Petis & Rp 23.249 .300 & $\begin{array}{ll}\text { Rp } & 44.794 .595\end{array}$ & $\operatorname{Rp} 21.545 .295$ & Undercosted \\
\hline 5 & Abon & $\operatorname{Rp} \quad 79.899 .400$ & $\operatorname{Rp} 106.438 .919$ & $\operatorname{Rp} 26.539 .519$ & Undercosted \\
\hline \multirow[t]{2}{*}{6} & Teri Krispi & $\mathrm{Rp} \quad 91.419 .300$ & Rp 59.034 .920 & $\operatorname{Rp} 32.384 .380$ & Overcosted \\
\hline & Jumlah & Rp 617.366.600 & $R p$ 615.928.160 & Rp 1.438 .440 & \\
\hline
\end{tabular}

Sumber : hasil yang diolah, 2019

Tabel 5 menunjukkan perbandingan hasil perhitungan HPP antara metode tradisional dan ABC. Dua metode tersebut menimbulkan perbedaan pada nilai overhead pada masing-masing produk yang nantinya akan menimbulkan perbedaan pada penentuan harga produk. Terdapat tiga produk yang mengalami overcosting (penetapan biaya produk terlalu tinggi) yaitu kripik, krupuk dan teri krispi dengan nilai sebesar Rp. 20.111.951, Rp. 22.124.107, dan Rp. 32.384.380. sedangkan tiga produk lainnya mengalami undercosting (penetapan biaya produk terlalu rendah) yaitu dendeng, petis dan abon dengan nilai sebesar Rp. 25.097.184, Rp. 21.545.295, Rp. 26.539.519. Metode awal menyebabkan adanya distorsi biaya, karena dalam perhitungan biaya overhead, metode tradisional hanya memakai satu penyebab adanya biaya yang berkaitan dengan volume produksi. Hal ini berbeda dengan metode ABC yang memandang berbagai aktivitas yang terjadi pada setiap sub unit perusahaan.

\section{Analisis Aktivitas}


Adapun hasil analisis aktivitas UKM adalah sebagai berikut :

Tabel 6. Rasio Aktivitas

\begin{tabular}{ccr}
\hline No. & \multicolumn{2}{c}{ Rasio Aktivitas } \\
1 & Total Aset Turn Over & $3 \mathrm{X}$ \\
2 & Perputaran Piutang & $16 \mathrm{X}$ \\
\hline \multicolumn{2}{l}{ Sumber : hasil yang diolah, 2019}
\end{tabular}

Tabel 6 menunjukkan nilai total asset turn over sebesar 3x. Hal ini mengindikasikan bahwa perputaran dana keseluruhan aset rata-rata setahun $3 x$ atau setiap rupiah aset selama setahun menghasilkan revenue sebesar $\mathrm{Rp}$ 3,Sedangkan nilai perputaran piutang sebesar 16x, hal ini menunjukkan bahwa dalam setahun rata-rata dana yang tertanam pada piutang sebesar 16x.

\section{Analisis Kemandirian Keuangan}

Adapun hasil analisis kemandirian keuangan UKM adalah sebagai berikut :

Tabel 7. Hasil Analisis Kemandirian Keuangan UKM

\begin{tabular}{lcc}
\hline \multicolumn{1}{c}{ Jenis Rasio } & Nilai & Predikat \\
\hline a. Rentabilitas Aset & 78,23 & Sehat \\
b. Rentabilitas Modal Sendiri & 97,48 & Sehat \\
c. Kemandirian Operasional & 453,85 & Sehat \\
\hline
\end{tabular}

Sumber : hasil yang diolah, 2019

Tabel 7 menunjukkan hasil analisis kemandirian keuangan UKM melalui tiga indikator. Nilai rentabilitas aset sebesar 78,23\% (>10), nilai rentabilitas modal sendiri 97,48\% (>10) dan nilai kemandirian operasional sebesar 453,85\% (>100). sehingga dapat disimpulkan bahwa dari tiga indikator pengukuran kemandirian keuangan, UKM masuk dalam kategori sehat.

\section{PENUTUP}

Adapun kesimpulan yang dapat diberikan dari penelitian ini adalah sebagai berikut : Produk yang mengalami undercosting atau biaya dibebankan terlalu sedikit adalah produk dendeng ikan, petis ikan dan abon ikan yaitu sebesar Rp 25.097.184,- ; Rp 21.545.295,- ; Rp 26.539.519,-, sedangkan produk kripik (kapasan dan jambrong), krupuk (ikan, cumi dan lele), dan teri krispi mengalami overcosting atau biaya dibebankan terlalu banyak sebesar Rp 20.111.951,- ; Rp 22.124.107,- ; Rp 32.384.380,-. Berdasarkan hasil analisis aktivitas 
menunjukkan bahwa UKM ini tergolong efektif dalam memanfaatkan sumberdaya yang dimilikinya. Hal ini ditunjukkan dengan hasil rasio aktivitas yang lebih besar dari Standar Rasio Industri Aktivitas yaitu nilai Total Aset Turn Over sebesar 3x $(>2 x)$ dan Perputaran Piutang sebesar 16x $(>15 x)$. Serta tingkat kemandirian keuangan UKM tergolong dalam kategori sehat, hal ini terlihat dari nilai rentabilitas aset dan rentabilitas modal sendiri yang lebih besar dari 10 serta nilai kemandirian operasional UKM yang lebih besar dari 100.

Adapun dari keterbatasan penelitian yang ada, maka peneliti menyarankan agar pihak manajemen UKM sebaiknya mulai mempertimbangkan proses perhitungan Harga Pokok Produksi (HPP) dengan mengunakan metode Activity Based Costing dengan tetap mempertimbangkan faktor eksternal seperti daya beli konsumen dan kompetitor. Serta tetap mempertahankan tingkat kesehatan keuangannya dan tidak mudah tergiur tawaran-tawaran menarik dari pihak bank atau kreditor lain dengan motif ekspansi usaha menggunakan modal pinjaman. Terakhir, penulis ingin mengucapkan terima kasih kepada Ristekdikti atas pendanaan yang telah diberikan pada penelitian ini.

\section{DAFTAR PUSTAKA}

A'isyah, F. S., \& Azizah, D. F. (2013). Penerapan Activity Based Costing System (ABC System) Dalam Penentuan Harga Pokok Produksi (Hpp)(Studi Kasus Pada Perusahaan Rokok Djagung Prima Malang 2011). Jurnal Administrasi Bisnis, 2(1), 47-56.

Aminatuzzahra \& Mawardi, Wisnu. (2010). Analisis Pengaruh Current Ratio, Debt To Equity Ratio, Total Asset Turnover, Net Profit Margin Terhadap Roe (Studi Kasus Pada Perusahaan Manufaktur Go-Public di BEI Periode 2005-2009). Undergraduate thesis. Universitas Diponegoro.

Arikunto, S. (2016). Prosedur Penelitian Suatu Pendekatan Praktik. Jakarta: Rineka Cipta.

Kapojos, R., Sondakh, J. J., \& Waladouw, S. (2014). Penerapan Metode Activity Based Costing Dalam Penentuan Harga Pokok Produksi Pada Perusahaan Roti Lidya Manado. Jurnal EMBA: Jurnal Riset Ekonomi, Manajemen, Bisnis dan Akuntansi, 2(2).

Kasmir. (2016). Analisis Laporan Keuangan. Jakarta: Raja Grafindo Persada. 
Mulyadi. (2015). Akuntansi Biaya. Edisi 5. Yogyakarta : Sekolah Tinggi Ilmu Manajemen YKPN.

Puspitawati, D. I. (2013). Analisis kinerja kemandirian keuangan dan aktivitas layanan rawat inap utama pada badan layanan umum daerah rumah sakit jiwa menur dengan metode activity based costing. Die, 10(1).

Putri, D. A., \& Sabeni, A. (2011). Analisis Penggunaan Metode Activity Based Costing Sebagai Alternatif Dalam Menentukan Tarif SPP SMP-SMA Pada YPI Nasima Semarang Tahun 2010. Doctoral dissertation. Universitas Diponegoro.

Rajabi, A., \& Dabiri, A.(2012). Applying activity based costing (ABC) method to calculate cost price in hospital and remedy services. Iranian journal of public health, 41(4), 100.

Saputri, H. E. (2013). Analisis Penentuan Harga Pokok Produksi Tas Berdasarkan Sistem Activity Based Costing Pada Perusahaan Tas Monalisa. Doctoral dissertation. Universitas Negeri Semarang.

Sedarmayanti. (2012). Manajemen Sumber Daya Manusia. Jakarta : Refika Aditama Eresco.

Soemarso. (2010). Akuntansi: Suatu Pengantar. Cetakan Keempat. Jakarta: Salemba Empat

Sugiyono. (2017). Metode Penelitian Kuantitatif, Kualitatif, dan RED. Bandung: Alfabeta, CV.

Tyasasih, R., \& Pramitasari, T. D. (2019). Analisis Perhitungan Harga Pokok Produksi Berdasarkan Fungsi (Metode Tradisional). In Prosiding Seminar Nasional \& Call For Paper (pp. 213-220). 